\title{
Coupling Analysis of Hydrometeorology and Erosive Landforms Evolution in Loess Plateau, China
}

\author{
N. N. Cheng, ${ }^{1,2}$ H. M. He, ${ }^{1,3}$ Y. J. Lu, ${ }^{3}$ and S. Y. Yang ${ }^{4}$ \\ ${ }^{1}$ State Key Laboratory of Soil Erosion and Dryland Farming on the Loess Plateau, Institute of Soil and Water Conservation, \\ CAS and MWR, Yangling, Shaanxi 712100, China \\ ${ }^{2}$ University of Chinese Academy of Sciences, Beijing 100049, China \\ ${ }^{3}$ Institute of Soil and Water Conservation, Northwest A\&F University, Yangling, Shaanxi 712100, China \\ ${ }^{4}$ Department of Forestry, Mississippi State University, Starkville, MS 39759, USA
}

Correspondence should be addressed to H. M. He; hongming.he@yahoo.com

Received 30 April 2015; Accepted 14 July 2015

Academic Editor: Pedro Salvador

Copyright (C) 2016 N. N. Cheng et al. This is an open access article distributed under the Creative Commons Attribution License, which permits unrestricted use, distribution, and reproduction in any medium, provided the original work is properly cited.

\begin{abstract}
The purpose of this study is to investigate hydrometeorology changing patterns impacts on erosive landforms evolution in Loess Plateau in the past 60 years (1950-2010). We firstly describe hydrometeorology changing patterns (rainfall-runoff-soil erosion response) at different time scales (daily, monthly, and yearly) in perspective of river basins and then further investigate hydrometeorology impacts on erosive landform through combined analysis of statistical quantification and proposed conceptual model of rainfall-runoff-soil erosion landform. Through the above investigations, the following findings are achieved. Firstly, it shows that annual runoff and sediment discharges decreased obviously although precipitation remained at the same level in the past 50 years (1960-2010). Discharges of annual runoff and sediment decreased by $30 \%-80 \%$ and $60 \%-90 \%$, respectively. Secondly, contributors of soil erosion are determined by integrated factors such as precipitation, river network, and topography characteristics of river basins. The strong soil erosion area existed in the middle hilly-gully region, while the high precipitation was in southern mountains. Thirdly, erosion landform development was largely shaped by hydrometeorology characteristics in comparison with other contributors. It shows that there is strong positive relationship between precipitation and erosion.
\end{abstract}

\section{Introduction}

Soil erosion has been one of the most triggering environmental issues for decades for its destructive effects [1-7]. Soil erosion deteriorates natural environment and socioeconomic properties as well, such as soil quality, agricultural production, ecosystem stability, and Loess of socioeconomic properties [8-10]. Soil erosion, which is classified into different categories (water, wind, glacier, gravity, and human erosions), is caused by contributors such as climate (e.g., rainfall), topography (slope, river network), vegetation and land use cover, and human activities. Soil erosion patterns changed with the changes of these contributors. For example, Mediterranean environments in Spain have become more prone to soil erosion [11], Alpine areas have a high risk for soil erosion associated with the extreme climatic and topographic conditions, and sediments of Mississippi River, Nile River, and Mekong River also changed significantly during the last several decades [12-16] because of climate change and human activities [17-19]. Sediment yield is primarily controlled by plan curvature and highest-order channel length, followed by hypsometric integral, rainfall, basin relief, and so forth. In Loess Plateau, watershed shape parameters and relief parameters are the major factors that affect sediment yield [20]. With construction of dams and reservoirs, watershed longitudinal linkages are weakened which caused decrease of sediment yield, while natural vegetation clearance and mining activity reduce resistance of land surface and enhance the effectiveness of flow on sediments, thus increasing sediment yield $[21,22]$. In Loess Plateau, precipitation decrease is the main reason for reduction of sediment transport, and their spatiotemporal patterns are consistent in the last several decades. Contribution rate of human activities is $61 \%-93 \%$ 
to decrease of sediment discharge in 10 tributaries of Yellow River's middle reach [23].

Various approaches were developed to investigate soil erosion and its related issues, including field observation, laboratory test, quantitative analysis, and model simulation $[13,24]$. Field observations provide the first hand data for soil erosion investigations $[21,25]$. Mathematical statistics mainly focus on the trend analysis, test of observed streamflow, and precipitation, which include parametric and nonparametric tests. Nonparametric tests are generally used to quantify hydrological parameters; for example, Mann-Kendall Test has been widely used for trend analysis [26-30]. Geographic statistics is mainly used for spatial distribution analysis of observed data. However, the statistical methods cannot reveal the physical process and relations of hydrological parameters and explain the reasons of change. As a result, mathematical and hydrological models have been widely used. Hydrological models are commonly applied to effectively and efficiently analyze changes of hydrological parameters and their response to climate change, human activities, and landform evolution. Soil and Water Assessment Tool (SWAT) model, Distributed Biosphere-Hydrological (DBH) model, and Community Land Model (CLM4) version 4 were often used to investigate response of streamflow to LUCC, climate change, and human activities [31]. The Universal Soil Loss Equation [32] and its successors, the Revised Universal Soil Loss Equation (RUSLE), are by far the most often used models for soil erosion predictions. USLE and WEEP were used to study fluctuations of soil erosion on the influence of rainfall, vegetation coverage, conservation measures, and land use [33-36].

Loess Plateau has been experiencing severe soil erosion for decades influenced by climatic change, hydrology change, and human activities [37-40]. Previous investigations show that rainfall density played an important role in soil erosion process compared to other features in Loess Plateau [41, 42]. Land use is critical in controlling soil erosion in this area $[43,44]$, and it was reported that soil erosion decreased dramatically with the increase of vegetation cover during the past decades in Loess Plateau. Soil erosion intensity, process, and mechanism are influenced by topographic factors such as slope, water velocity, amount of penetration, and runoff amount in Loess Plateau [20, 45-49]. Soil erosion closely related to the sediment transportation in the middle Yellow River. Changes of sediment in the mainstreams of the middle Yellow River reflected the changes of soil erosion in Loess Plateau [50]. These investigations provide abundant background knowledge in soil erosion in Loess Plateau. However, these studies mainly focus on spatiotemporal characteristics of soil erosion and climate change at large scales and rainfall and erosion process at watershed scale. Interaction between hydrometeorology and erosive landform evolution in Loess Plateau remains unclear. Coupling response of soil erosion and landform evolution has not been quantitatively analyzed in detail, especially in Loess Plateau. Therefore, it is necessary to carry out coupling analysis and quantitative investigation of hydrometeorology and erosive landform evolution in Loess Plateau. The purpose of this study is to investigate hydrometeorology changing patterns impacts on erosive landforms

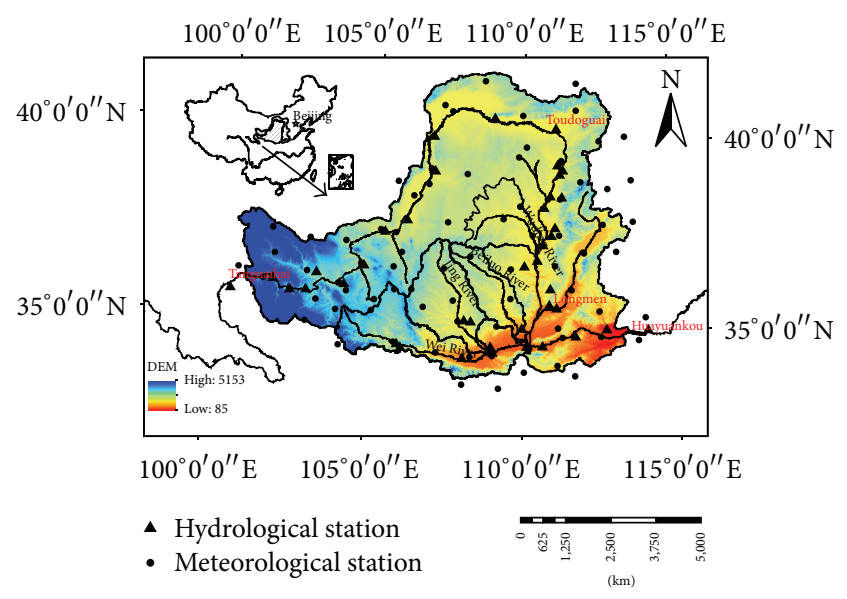

FIGURE 1: Sketch map and DEM of the study area (Loess Plateau) (triangle, hydrological gauged stations; rectangle, meteorological station).

evolution in Loess Plateau in the past 60 years (1950-2010) through combined analysis of statistical quantification and proposed conceptual model of rainfall-runoff-soil erosion landform. We firstly describe hydrometeorology changing patterns (rainfall-runoff-soil erosion response) at different time scales (hourly, daily, monthly, and yearly) from the perspective of river basins and then analyze hydrometeorology and erosive landforms evolution.

\section{Study Area}

The Loess Plateau $\left(100^{\circ} 54^{\prime}\right.$ to $114^{\circ} 33^{\prime} \mathrm{E}$ and $33^{\circ} 43^{\prime}$ to $\left.41^{\circ} 16^{\prime} \mathrm{N}\right)$ which covers $624,000 \mathrm{~km}^{2}$ with over $60 \%$ subjected to soil and water losses is mainly located in the middle reaches of the Yellow River $(3943 \mathrm{~km}$ ) (Figure 1). The average annual precipitation on the Loess Plateau ranges from $250 \mathrm{~mm}$ to $600 \mathrm{~mm}$, which gradually increases from northwest to southeast. Precipitation of rainy season (from June to September) accounts for $60-70 \%$ of the total of the year. Heavy rain in form of rainstorms occurs frequently in rainy season which causes flood and severe soil erosion. Strong erosion forms specific geomorphologic features with many gullies and fragmented landforms in Loess Plateau. Tableland (Yuan), ridges (Liang), and hills (Mao) are typical erosion landforms of Loess Plateau. Gully erosion accounts for more than $80 \%$ of the soil erosion in this area. Gully density and segmentation of the ground are as high as $8 \mathrm{~km} / \mathrm{km}^{2}$, and segmentation of the ground is about $43.7 \%$ in some area. The average erosion modulus reaches $5000-10000 \mathrm{t} \cdot \mathrm{km}^{-2} \cdot \mathrm{a}^{-1}$, sometimes even reaching to $20000-30000 \mathrm{t} \cdot \mathrm{km}^{-2} \cdot \mathrm{a}^{-1}$, and it decreased to $2205.4 \mathrm{t} \cdot \mathrm{km}^{-2} \cdot \mathrm{a}^{-1}$ in He-Long region in 2011 [51]. The sediment discharge of He-Long section of Yellow River was about $3.1 \times 10^{8} \mathrm{t}$ during 1980-2010 and $1.6 \times 10^{8} \mathrm{t}$ during 2000-2010 [51]. Vegetation destruction was one of the key contributors to soil erosion in Loess Plateau for decades because of improper human activities (such as cultivation, deforestation, and development of economy). However, it improved a lot after implementation of Grain-for-Green 
Project in 1990s with increase of grassland cover (30.5\% of the total) and forest $(12.0 \%$ of the total) in Loess Plateau. What is more, the vegetation improved after a large number of ecological engineering projects such as check dams, terraces, and reforestation were implemented.

\section{Materials and Methodology}

3.1. Data Sources and Materials. In this study, precipitation and hydrology datasets were obtained from the hydrological and meteorological stations of Loess Plateau (Figure 1), and topographic datasets were extracted from digital elevation model (DEM). All these datasets are used to investigate hydrometeorology changing patterns impact on erosive landforms evolution in Loess Plateau in the past 60 years. The meteorological datasets of 76 observation stations, which include daily, monthly, and annual precipitation during 19602011, were used to illustrate situations of climate change and human activities in Loess Plateau. Precipitation datasets are further trimmed and classified as erosive precipitation and rainstorms in terms of rainfall intensity. For example, an erosive precipitation is defined when daily precipitation is equal or larger than $12 \mathrm{~mm} / \mathrm{d}$ [52], while it is defined as rainstorm if daily precipitation is equal or larger than $50 \mathrm{~mm} / \mathrm{d}$. These datasets were provided by National Meteorological Information Center (NMIC), China Meteorological Administration (CMA). The hydrological datasets of 41 gauge stations were used to carry out hydrometeorological analysis and soil erosion as well. These datasets include daily streamflow and sediment discharge from 1960 to 2011. Among these 41 gauges stations, 5 stations are located in the mainstream of the middle Yellow River, including Tangnaihai, Toudaoguai, Longmen, Tongguan, and Huayuankou, which will be emphasized in this study. These datasets were provided by Ecological Environment Database of Loess Plateau, Chinese Academy of Sciences and Ministry of Water Resources (CAS\&MWR). Topographic parameters, such as gully density, slope, relief amplitude (RDLS), and river network, were extracted from 30-meter resolution DEM which was downloaded from International Scientific and Technical Data Mirror Site, Computer Network Information Center of Chinese Academy of Sciences.

\subsection{Analysis of Hydrometeorological Spatiotemporal Distribu-} tion. Hydrometeorological spatiotemporal distribution patterns were analyzed by using Mann-Kendall Test (Mann, 1945; Kendall, 1975), Geographic Information System approaches, for example, Inverse Distance Weighted (IDW) [53]. Mann-Kendall Test is applied for detecting changing points in hydroclimatic time series. Meanwhile, temporal characteristics and relationships of precipitation, runoff and sediment in Loess Plateau, and the middle Yellow River basin were also described by Mann-Kendall Test. Changing patterns of climatic and hydrologic spatial distributions were illustrated by spatial interpolation technique, the Inverse Distanced Weighted (IDW). Topographic parameters were further analyzed after extraction from DEM, such as gully density, slope, aspect, relief, and river network, which were extracted from 30-meter resolution DEM. In comparison, soil erosion landforms in different river basins were characterized through these topographic parameters.

3.3. Erosive Landform Evolution Index for Soil Erosion and Landform Evolution. To quantify soil erosion contributors to landform evolution, we proposed an Erosive Landform Evolution Index (ELEI) for description of soil erosion and landform evolution in Loess Plateau. Considering the complexity of landforms and contributors to soil erosion, those parameters of gully density, relief amplitude (RDLS), and hilly slope are chosen to quantify landform changes, and precipitation, runoff, and sediment are defined as primary parameters of soil erosion. Landform evolution change $\left(\mathrm{Ev}_{\text {Landform }}\right)$ is function of gully length $\left(L_{g}\right)$, relief amplitude $\left(A_{r}\right)$, and hilly slope $\left(S_{h}\right)$. Soil erosion intensity $\left(\operatorname{Er}_{\text {landform }}\right)$ is function of precipitation $(P)$, runoff $(R)$, and sediment transportation $(S)$. Erosive Landform Evolution Index (ELEI) is function of landform evolution change $\left(\mathrm{Ev}_{\text {landform }}\right)$ and soil erosion intensity $\left(\mathrm{Er}_{\text {landform }}\right)$. By using the principal components analysis (PCA), we can select comprehensive factors for landform evolution change $\left(\mathrm{Ev}_{\text {landform }}\right)$ and soil erosion intensity $\left(\mathrm{Er}_{\text {landform }}\right)$ from parameters of Erosive Landform Evolution Index (ELEI) and climate factors and establish functions for landform evolution change $\left(\mathrm{Ev}_{\text {landform }}\right)$ and soil erosion intensity $\left(\mathrm{Er}_{\text {landform }}\right)$. Meanwhile, we can also build the function between $\mathrm{Ev}_{\text {landform }}$ and $\mathrm{Er}_{\text {landform }}$ by using linear regression analysis:

$$
\begin{aligned}
\mathrm{Ev}_{\text {landform }} & =F\left(L_{\text {gully }}, A_{\text {relief }}, S_{\text {hilly }}\right), \\
\mathrm{Er}_{\text {landform }} & =G(P, R, S), \\
\text { ELEI } & =H(F, G) .
\end{aligned}
$$

According to referenced geomorphological mapping taxonomy, it defines RDLS as flat $(0-20 \mathrm{~m})$, small $(20-75 \mathrm{~m})$, middle (75-300 m), mountain (300-600 m), and high moun$\operatorname{tain}(>600 \mathrm{~m})$. On the basis of characteristics of DEM in Loess Plateau, the slope can be defined as 5 grades $\left(<3^{\circ}, 3 \sim 7^{\circ}, 7 \sim 15^{\circ}\right.$, $15 \sim 25^{\circ}$, and $\left.>25^{\circ}\right)$. In this study, we calculated percentages of different RDLS and slope.

\section{Results}

4.1. Changing Patterns of Rainfall-Runoff-Soil Erosion Process in the Loess Plateau (1950-2010). Changes of precipitation, runoff, and sediment displayed different patterns during the past 60 years (1950-2010). Although annual precipitation had no obvious change, average annual runoff has decreased by $30 \%-80 \%$, and sediment discharge has decreased by $60 \%-$ $90 \%$ in 2000s in comparison with those in 1960s. Figure 2 displays distribution of annual rainfall, rainfall erosivity (rainfall erosivity is the kinetic energy of raindrop's impact and the rate of associated runoff, $\mathrm{MJ} \cdot \mathrm{mm} \cdot \mathrm{ha}^{-1} \cdot \mathrm{h}^{-1} \cdot \mathrm{yr}^{-1}$ ), and specific soil yield (SSY refers to sediment export per unit area, $\mathrm{Mg} \cdot \mathrm{km}^{-2} \cdot \mathrm{y}^{-1}$ ) from 1960 to 2010. It shows that only four stations in the west and north part indicate increasing trend $\left(0-1.7 \mathrm{~mm} \cdot \mathrm{y}^{-1}\right)$, and all the other stations present downward 

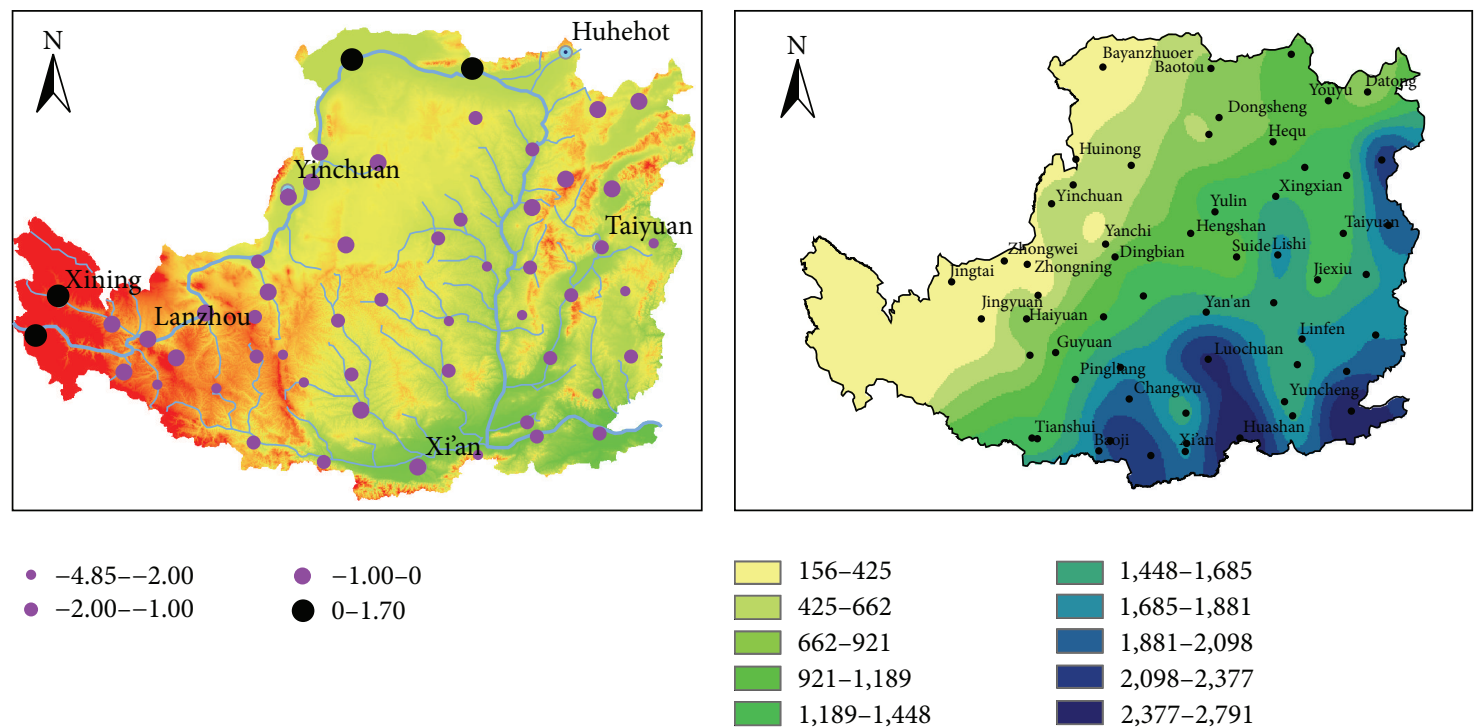

(a) Precipitation trend $(\mathrm{mm} / \mathrm{yr})$

(b) Rainfall erosivity $\left(\mathrm{MJ} \cdot \mathrm{mm} / \mathrm{hm}^{2} \cdot \mathrm{h} \cdot \mathrm{yr}\right)$
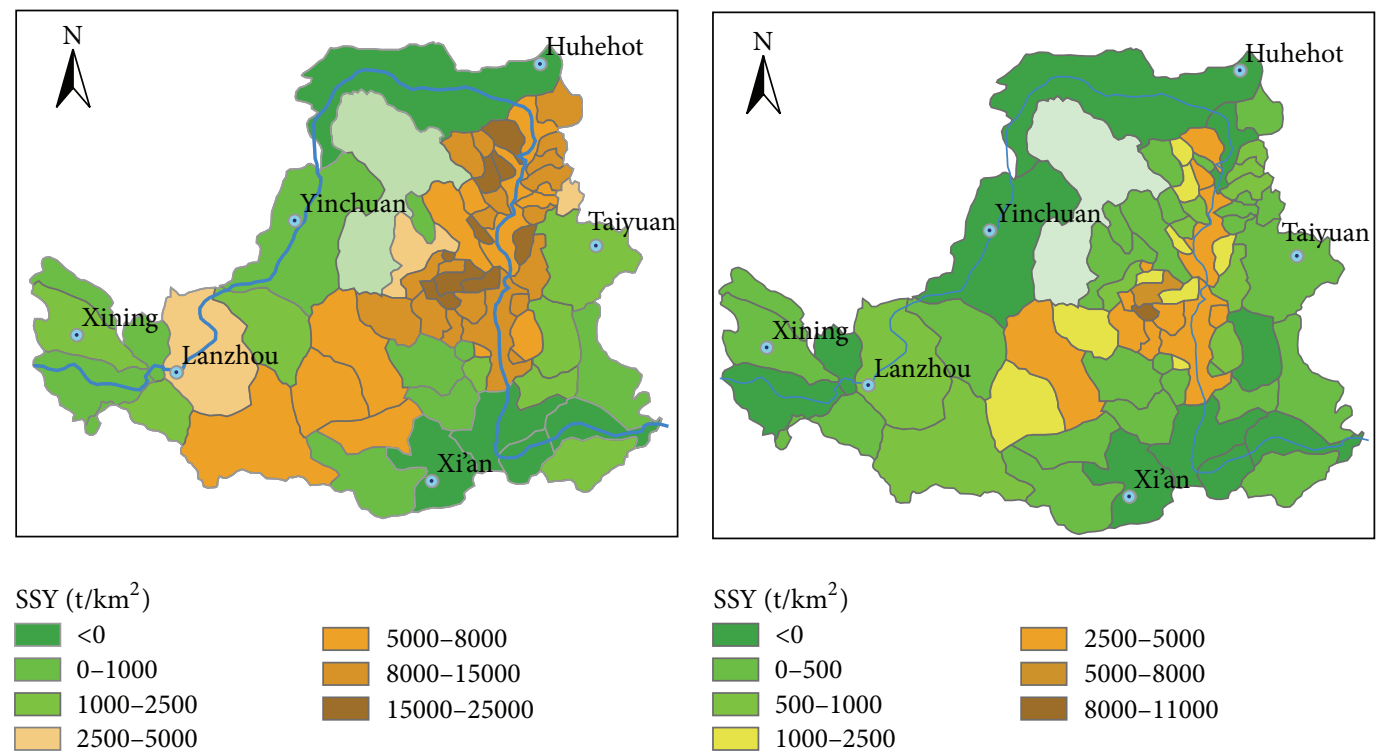

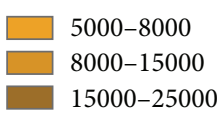

(c) $1955-1969$
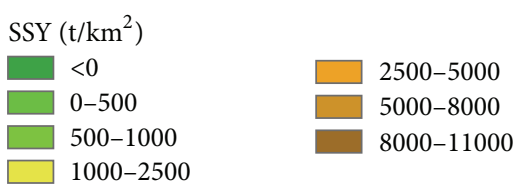

(d) 2000-2010

FIGURE 2: Distribution of precipitation, rainfall erosivity, and specific soil yield (SSY) in Loess Plateau (modified after [37]). ((a) Precipitation trend distribution map, (b) rainfall erosivity distribution map, (c) specific soil yield distribution map (1955-1969), and (d) specific soil yield distribution map (2000-2009)).

trend ranging from $-4.85 \mathrm{~mm}$ to $-0.02 \mathrm{~mm}$, particularly near Lanzhou and Yinchuan cities as well as the northeast of Loess plateau [37]. Further, through the Mann-Kendall Test, the change points of annual precipitation usually occur in late 1980s, and annual precipitation increased slightly after change points (Figure 3). Annual runoff of all hydrological stations decreased at $99 \%$ confidence interval during the past 50 years, and the significant change often began after 1980s $(p=0.01)$ through the Man-Kendall Test. Spatial distribution of average annual Specific Sediment Yield on Loess Plateau within the two periods. During the period from 1955 to 1969, the most severe soil erosion regions with SSY higher than
$8,000 \mathrm{Mg} \cdot \mathrm{km}^{-2} \cdot \mathrm{y}^{-1}$ lie in the section between Toudaoguai and Longmen stations (Figure 1), which is also called "the Coarse Sandy Hilly Catchments" [19]. This region covers an area of $7.86 \times 104 \mathrm{~km}^{2}$, accounting for only $14.8 \%$ of the whole Yellow River basin but producing nearly $80 \%$ of the coarse sediment to the Yellow River [37]. Obviously, heavy rain causes increase in runoff and the tendencies of them are consistent, but the impact of precipitation is postponed because of runoff and flood process. In Loess Plateau, more than $50 \%$ of annual precipitation and runoff concentrate during the rainy season (June, July, August, and September), and soil erosion is mainly caused by heavy rainfall (Figure 4). 


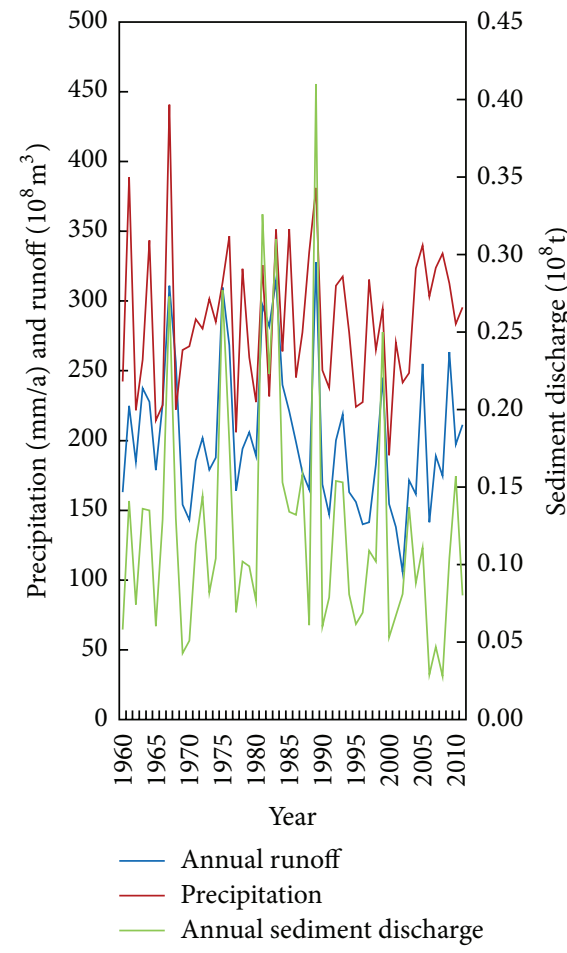

(a)

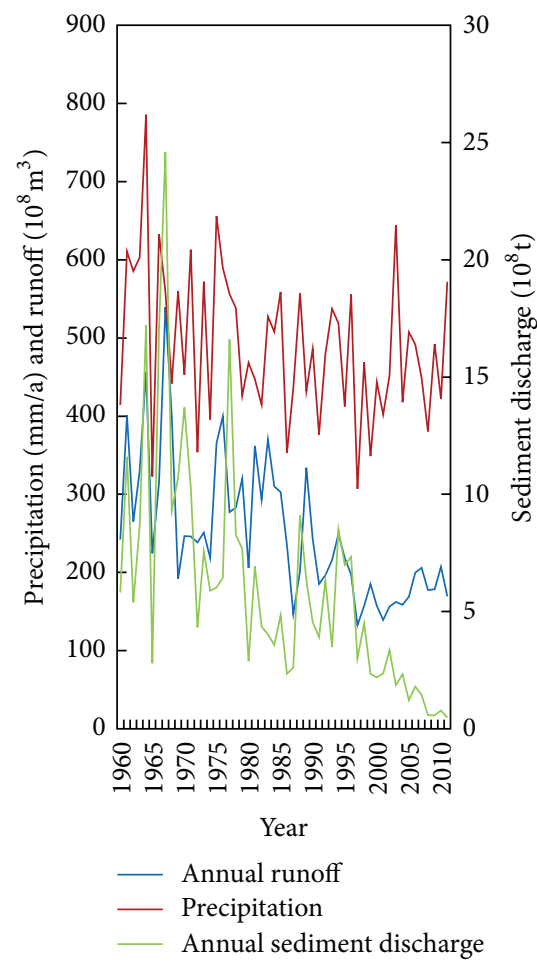

(c)

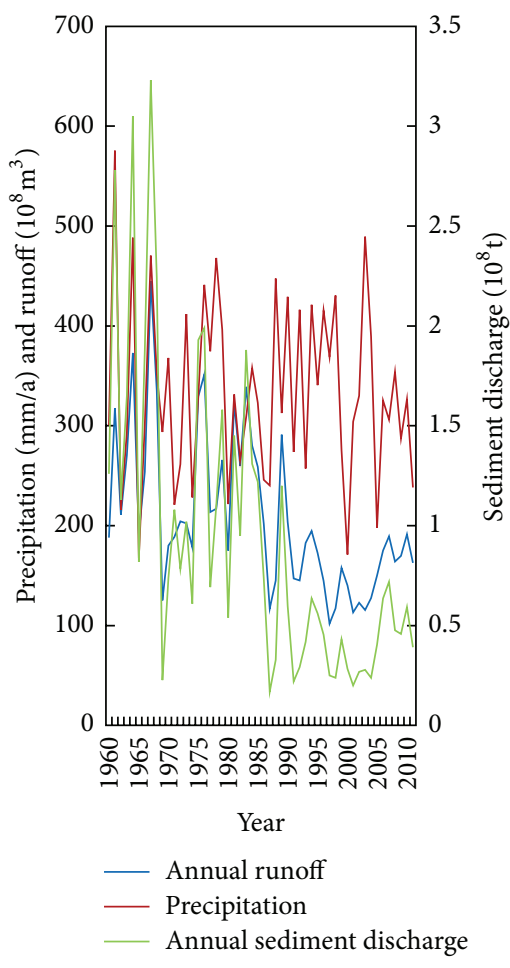

(b)

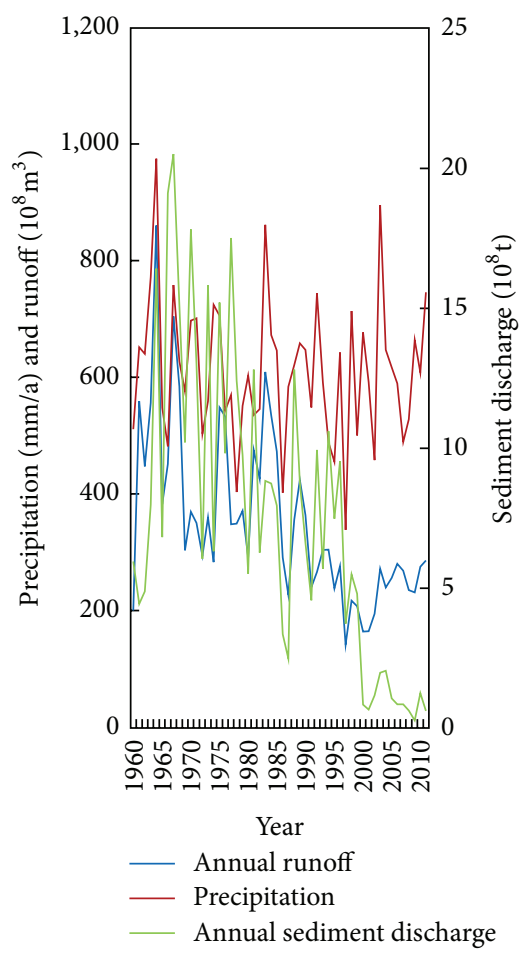

(d)

Figure 3: Changes of annual precipitation, runoff, and sediment discharge during the past 50 years (1960-2010) ((a) Tangnaihai, (b) Toudaoguai, (c) Longmen, and (d) Huayuankou). 


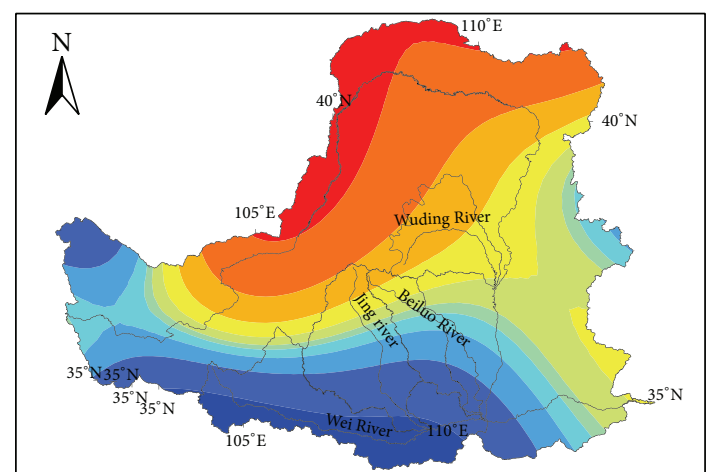

$0-24.8$

$24.8-38.7$

$38.7-46.5$

$46.5-50.8$

$50.8-53.3$

(a) Erosive precipitation frequency

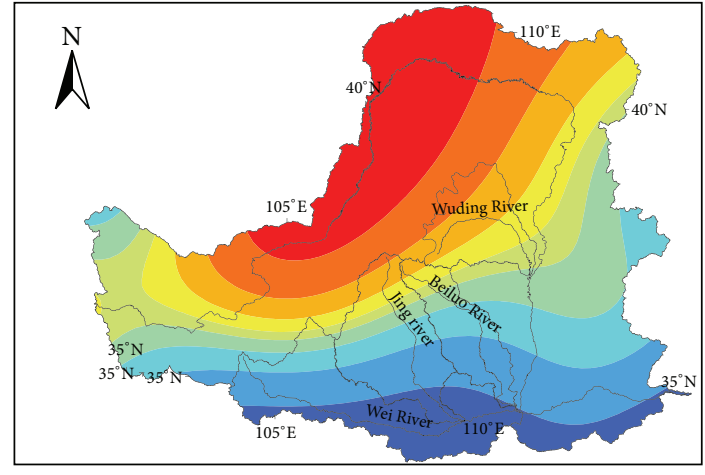

$7.9-14.8$

$14.8-19.3$

$19.3-22.2$

$22.2-24.2$

$24.2-25.5$

(b) Rainstorm frequency

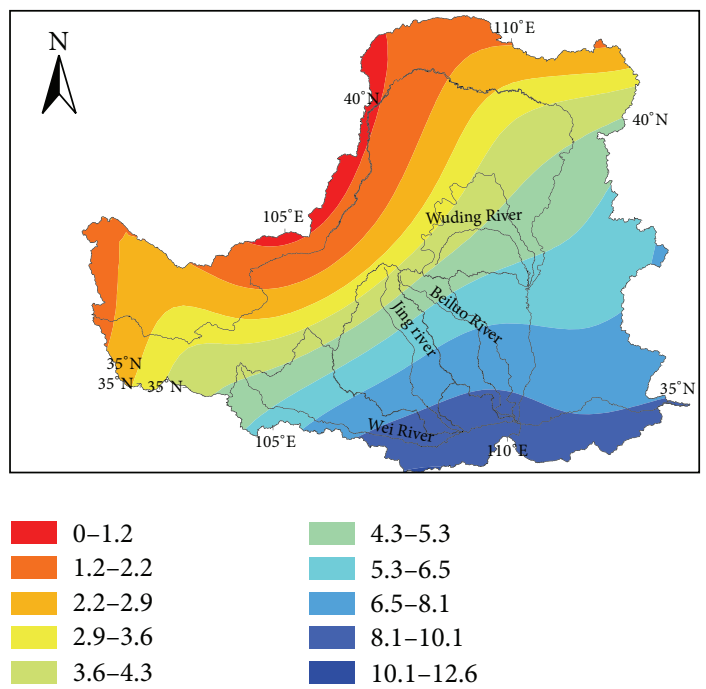

(c) Heavy rainstorm frequency

FIGURE 4: Frequency of different rainfall types ((a) erosive precipitation, (b) rainstorm, and (c) heavy rainstorm).

It is obvious that there were time lags between rainfall and runoff, runoff, and sediment transportation in the observed stations. For example, precipitation peak was on the 18th day at Tangnaihai station in 1967 , the nearest runoff began to increase on the 22nd day, and the runoff peak was on the 35 th day; in 1976, the peaks of runoff were about 4-8 days late compared to that of precipitation.

Differences between precipitation and runoff and sediment increased from upstream to downstream in the mainstream of upper and middle Yellow River, although precipitations fluctuated at around a certain level. And sediment decreased much more than runoff. Higher precipitation of these cities (Tangnaihai, Toudaoguai, Longmen, Tongguan, and Huayuankou) which locate from the upper of Yellow River to lower of it corresponded to higher runoff and sediment from 1960 to 2010. Correlation between precipitation and runoff is positive $(r=0.565, p<0.01)$, and it is much more obvious during 1960 and 1990. In 1960s and 1970s, change of runoff was mainly caused by fluctuation of rainfall. With development of society and increase of human activities, factors influencing runoff increased, and the coupling relationship between rainfall and runoff has become more complex. Moreover, annual runoff increases from upstream to downstream as well as annual precipitation.

Although annual precipitation fluctuates during the study period, annual runoff sediment discharge decreased obviously. However, runoff peaks correspond with rainfall events, especially for rainstorm (daily rainfall is larger than $50 \mathrm{~mm} / \mathrm{d}$ ). Sediment discharge does not display well correlations with precipitation; as a result, sediment discharge (soil erosion) is mainly influenced by vegetation, land cover, and human activities. The relationship of rainstorm and runoff can correspond well. In July of 1977 at Pingliang, there was a rainstorm which lasted for 19 hours and covered $33200 \mathrm{~km}^{2}$. 
TABLE 1: Parameters configuration of Erosive Landform Evolution Index (ELEI).

\begin{tabular}{|c|c|c|c|c|}
\hline Parameters of Erosive Landform Evolution Index & Weihe River & Jinghe River & Beiluo River & Wudinghe River \\
\hline \multicolumn{5}{|l|}{ Gully } \\
\hline Gully density $\left(\mathrm{km} / \mathrm{km}^{2}\right)$ & 0.13 & 0.15 & 0.15 & 0.13 \\
\hline Runoff $\left(10^{8} \mathrm{~m}^{3}\right)$ & 64.62 & 16.01 & 8.16 & 10.86 \\
\hline Sediment discharge $\left(10^{8} \mathrm{t}\right)$ & 2.94 & 2.08 & 0.68 & 0.92 \\
\hline \multicolumn{5}{|l|}{ RDLS } \\
\hline $0-20$ & $0.44 \%$ & $0.23 \%$ & $0.61 \%$ & $1.67 \%$ \\
\hline $20-75$ & $5.81 \%$ & $1.01 \%$ & $3.96 \%$ & $37.30 \%$ \\
\hline $75-300$ & $29.82 \%$ & $52.36 \%$ & $58.94 \%$ & $53.12 \%$ \\
\hline $300-600$ & $42.31 \%$ & $44.49 \%$ & $36.45 \%$ & $7.85 \%$ \\
\hline $600-\max$ & $21.62 \%$ & $1.91 \%$ & $0.04 \%$ & $0.06 \%$ \\
\hline Runoff $\left(10^{8} \mathrm{~m}^{3}\right)$ & 64.62 & 16.01 & 8.16 & 10.86 \\
\hline Sediment discharge $\left(10^{8} \mathrm{t}\right)$ & 2.942 & 2.083 & 0.682 & 0.916 \\
\hline \multicolumn{5}{|l|}{ Slope $\left(^{\circ}\right)$} \\
\hline $0 \sim 5$ & $24.32 \%$ & $16.69 \%$ & $19.12 \%$ & $57.46 \%$ \\
\hline $6 \sim 15$ & $38.14 \%$ & $40.77 \%$ & $41.05 \%$ & $27.89 \%$ \\
\hline $16 \sim 25$ & $23.98 \%$ & $32.75 \%$ & $29.54 \%$ & $11.94 \%$ \\
\hline $26 \sim 35$ & $9.56 \%$ & $6.24 \%$ & $8.85 \%$ & $2.31 \%$ \\
\hline $36 \sim 40$ & $2.20 \%$ & $2.92 \%$ & $0.88 \%$ & $0.22 \%$ \\
\hline $41 \sim 45$ & $1.08 \%$ & $0.30 \%$ & $0.31 \%$ & $0.09 \%$ \\
\hline $46 \sim \max$ & $0.73 \%$ & $0.34 \%$ & $0.24 \%$ & $0.09 \%$ \\
\hline Runoff $\left(10^{8} \mathrm{~m}^{3}\right)$ & 64.62 & 8.16 & 16.01 & 10.86 \\
\hline Sediment discharge $\left(10^{8} \mathrm{t}\right)$ & 2.942 & 0.682 & 2.083 & 0.916 \\
\hline \multicolumn{5}{|l|}{ ELEI } \\
\hline Gully length (km) & 9334.05 & 3501 & 5865.51 & 4414.58 \\
\hline RDLS $\left(\mathrm{km}^{2}, 20-600 \mathrm{~m}\right)$ & 48825.22 & 26755.75 & 44496.04 & 29713.77 \\
\hline Slope $\left(\mathrm{km}^{2}, 0-25^{\circ}\right)$ & 54150.01 & 24294.27 & 40790.31 & 29417.45 \\
\hline
\end{tabular}

Its rainfall was $255 \mathrm{~mm}$, and the maximum peak flow was $5220 \mathrm{~m}^{3} / \mathrm{s}$. In August of 1984 at Zhengning, there was a rainstorm which lasted for 6 hours and covered $423 \mathrm{~km}^{2}$, and the maximum peak flow was $586 \mathrm{~m}^{3} / \mathrm{s}$. In May of 1985 at Zhenyuan, the rainstorm lasted for 2.5 hours and covered $480 \mathrm{~km}^{2}$ with $359 \mathrm{~mm}$ precipitation, the maximum peak flow of which was $1260 \mathrm{~m}^{3} / \mathrm{s}$. In July of 1996 at Qingyang, the rainstorm lasted for 19.5 hours and covered $33150 \mathrm{~km}^{2}$ with $257.2 \mathrm{~mm}$ precipitation, and the maximum peak flow was $4680 \mathrm{~m}^{3} / \mathrm{s}$.

Frequency of low intensity rainfall was higher than that of high intensity rainfall, and frequency of the same intensity rainfall is higher in downstream than that of upstream. The average annual precipitation increases from northwest to southeast, and the minimum annual precipitation $(46.80 \mathrm{~mm} /$ a) is in Linhe, Inner Mongolia, and the maximum annual precipitation (1262.3 mm/a) is in Huashan, Shaanxi. Overall, high rainfall (more than $720 \mathrm{~mm} / \mathrm{a}$ ) region mainly concentrates in south of Shaanxi province, and the low rainfall (less than $250 \mathrm{~mm} / \mathrm{a}$ ) is in Inner Mongolia, Ningxia province, and northwest of Gansu province. The tendency of average decade precipitation is consistent with that of average annual precipitation which increases from northwest $(138 \mathrm{~mm})$ to southeast $(819 \mathrm{~mm})$. In the typical reach of the Yellow River, sediment discharge and annual runoff of specific stations which are close to downstream are larger than others. It indicates that (a) the downward trend of sediment discharge in upstream catchment is more significant than that in downstream basins for the same grade tributaries and (b) the trend of annual runoff in downstream catchment is more significant than that in upstream basin. The trend of sediment discharge is similar to that of runoff which increases from upstream to downstream.

\subsection{Coupling Analysis of Soil Erosion and Landforms Evolution} in the Loess Plateau. Tectonic movements in Quaternary formed the basic topography in Loess Plateau. Based on the above analysis of rainfall, runoff, and sediment transport, we can observe that peaks of runoff and sediment discharge are consistent with rainfall peak with time lags, and time lags of runoff and sediment discharge became longer in downstream than that in upstream for a normal distribution rainfall.

As indicated in methodology section, the higher values of Erosive Landform Evolution Index (ELEI) represent late stage of landform erosion. Table 1 displays parameters configuration of Erosive Landform Evolution Index (ELEI). By using the PCA method, we can easily get a comprehensive factor to stand for the three landform factors (gully length, RDLS, and slope). Before the PCA process, we standardized the data of three landform factors because of the difference of 
TABLE 2: The proportion of covariance and first principal values of landform and climatic factors.

(a)

\begin{tabular}{lcccc}
\hline PRIN number & Eigenvalue & Difference & Proportion & Cumulative \\
\hline Landform factors & & & & \\
1 & 2.9524 & 2.9051 & 0.9841 & 0.9841 \\
2 & 0.0473 & 0.0470 & 0.0158 & 0.9999 \\
3 & 0.0003 & & 0.0001 & 1.0000 \\
\hline Climatic factors & & & & 0.9271 \\
1 & 2.7813 & 2.6352 & 0.0487 & 0.9271 \\
2 & 0.1461 & 0.0734 & 0.0242 & 00.9758 \\
3 & 0.0726 & & & 1.0000 \\
\hline
\end{tabular}

(b)

\begin{tabular}{lccccccc}
\hline Basins & Weihe River & Wudnghe River & Beiluohe River & Jinghe River & Fenhe River & Qinhe River & Yanhe River \\
\hline Landform factors & 2.7176 & 0.1526 & -0.3206 & 1.3861 & 0.1233 & -1.9096 & -2.1495 \\
Climatic factors & 3.3354 & -0.3999 & -0.4694 & 0.9867 & -0.7555 & -1.3332 & -1.3640 \\
\hline
\end{tabular}

TABLE 3: The estimation parameters of the regression modeling.

\begin{tabular}{|c|c|c|c|c|}
\hline Variable & Parameter estimate & Standard error & $t$ value & $p$ value \\
\hline \multicolumn{5}{|c|}{ Comprehensive factor of erosive landform } \\
\hline Intercept & 0 & 0.270 & 0 & 1.00 \\
\hline$E_{e}$ & 0.953 & 0.004 & 150.87 & $<0.003$ \\
\hline
\end{tabular}

the units. The results of PCA (Table 2) show that the proportion of first principal is $98.41 \%$ which has significant correlation with the three landform factors. So we choose the first principal components as the comprehensive factor of erosion landform; higher PRIN values mean higher development of the erosion landform. Furthermore, with the PCA results we build (2) between the first PRIN and landform factors. The equation indicates that the three landform factors have positive correlation with the comprehensive landform factor:

$$
Y_{e}=0.576 X_{1}+0.575 X_{2}+0.582 X_{3}, \quad(p<0.05)
$$

In the equation, the $Y_{e}$ is the comprehensive factor of erosion landform, $X_{1}$ is the standardized value of gully length, $X_{2}$ is the standardized value of waviness, and $X_{3}$ is the standardized value of slope.

On the other hand, we also applied the same PCA process of calculation of the comprehensive factor of erosion landform, to calculate the comprehensive effect of erosion landform. By using the data of effects of erosion landform (Table 2), we obtain the comprehensive effect of erosion landform based on these erosion landform effects (runoff, sediment, and rainfall volume). The results (Table 2) indicate that the proportion of first principal is $92.71 \%$, which means the first principal can explain all the erosion landform effects very well. Therefore, we select the first principal component as the comprehensive effect of erosion landform, and higher principal scores mean more influence on the erosion landform. The equation of comprehensive effect of erosion landform is as follows:

$$
E_{e}=0.570 Z_{1}+0.578 Z_{2}+0.584 Z_{3}, \quad(p<0.05),
$$

where the $E_{e}$ is the comprehensive effect of erosion landform, $Z_{1}$ is the standardized value of runoff, $Z_{2}$ is the standardized value of sediment, and $Z_{3}$ is the standardized value of rainfall volume.

Finally, by using regression analysis, we can figure out the relationship between the comprehensive factor and comprehensive effect of erosion landform. Via the first principal scores of both comprehensive indexes (Table 2) in seven basins, we can calculate the relationship between these two indexes. The results (Table 3) show that the erosion landform comprehensive factor has the significant correlation $(p<$ 0.003 ) with comprehensive effect of erosion landform, and the intercept of the model is not significant with erosion landform comprehensive factor $(p>0.05)$. Therefore we remove the intercept from the model.

Moreover, through the regression analysis we also obtain (4) between the erosion landform comprehensive factor and comprehensive effect. Meanwhile from the equation, we can also indicate that the erosion landform comprehensive factor has positive relationship with the effects of erosion landform. Therefore, the development level of erosion landform will increase as the effects values increase:

$$
Y_{e}=0.953 E_{e}, \quad(p<0.003) .
$$


In this equation, the $Y_{e}$ is the comprehensive factor of erosion landform and the $E_{e}$ is the comprehensive effect of erosion landform.

\section{Conclusion}

The aim of this study was to identify coupling relationship of soil erosion and landforms evolution under the background of climate change and human activities. Through mathematical statistics, regression analysis, and PCA method, it was found that the main effects of erosion landform are rainfall volume, runoff, and sediment in Chinese Loess Plateau. The results of PCA indicate that the erosion landform comprehensive factor is composed of the three landform factors, which are gully length, RDLS, and slope. It also shows that there is a significant positive relationship between erosion landform comprehensive factor and landform factors, and this means that these three factors can stand for erosion landform. Therefore, they can be used as evaluation factors of erosion landform. The results of multiregression analysis indicate that annual rainfall volume, runoff, and sediment are the main effects of erosion landform, and they drive the changes of landform in the Loess Plateau. Furthermore, both landform factors and erosion landform effects should be standardized before using them to build up the correlation model because standardization can reduce the influence of unequal units of these factors, which is a very important part in this modeling. Meanwhile, the regression results also show that there is also a significant positive linear relationship between the erosion landform comprehensive factor and its effects. As a result, the development level of erosion landform will increase as its effects' values increase. Thus, this study provides useful information on impacts of erosion landforms evolution and can be used to guide soil and water conservation and investigate landforms evolution.

\section{Conflict of Interests}

The authors declare that there is no conflict of interests regarding the publication of this paper.

\section{Acknowledgments}

The authors acknowledge with gratitude the research grants kindly provided by the Hundred-Talent Project of the Chinese Academy of Sciences (20110009, Dr. H. M. He), the Key Research Program of Chinese Academy of Sciences (KZZDEW-04), Innovation Frontier Project of Institute of Soil and Water Conservation of the Chinese Academy of Sciences, State Key Laboratory of Soil Erosion, and Dryland Farming on the Loess Plateau (10501-192). They acknowledge with gratitude the help of Dr. Zhao Guangju (Institute of Soil and Water Conservation of the Chinese Academy of Sciences \& Ministry of Water Resources) for supporting them with datasets to perfect their research.

\section{References}

[1] B. Fu, "Soil erosion and its control in the Loess Plateau of China," Soil Use \& Management, vol. 5, no. 2, pp. 76-82, 1989.
[2] S. Kang, L. Zhang, X. Song et al., "Runoff and sediment loss responses to rainfall and land use in two agricultural catchments on the Loess Plateau of China," Hydrological Processes, vol. 15, no. 6, pp. 977-988, 2001.

[3] J. L. M. P. De Lima, V. P. Singh, and M. I. P. de Lima, "The influence of storm movement on water erosion: storm direction and velocity effects," Catena, vol. 52, no. 1, pp. 39-56, 2003.

[4] P. Davison, M. G. Hutchins, S. G. Anthony, M. Betson, C. Johnson, and E. I. Lord, "The relationship between potentially erosive storm energy and daily rainfall quantity in England and Wales," Science of the Total Environment, vol. 344, no. 1-3, pp. 15-25, 2005.

[5] L. Chen, Z. Huang, J. Gong, B. Fu, and Y. Huang, "The effect of land cover/vegetation on soil water dynamic in the hilly area of the loess plateau, China," Catena, vol. 70, no. 2, pp. 200-208, 2007.

[6] J. Casalí, R. Gastesi, J. Álvarez-Mozos et al., "Runoff, erosion, and water quality of agricultural watersheds in central Navarre (Spain)," Agricultural Water Management, vol. 95, no. 10, pp. 1111-1128, 2008.

[7] W. Wei, L. Chen, B. Fu, and J. Chen, "Water erosion response to rainfall and land use in different drought-level years in a loess hilly area of China," Catena, vol. 81, no. 1, pp. 24-31, 2010.

[8] A. Gafur, J. R. Jensen, O. K. Borggaard, and L. Petersen, "Runoff and losses of soil and nutrients from small watersheds under shifting cultivation (Jhum) in the Chittagong Hill Tracts of Bangladesh," Journal of Hydrology, vol. 274, no. 1-4, pp. 30-46, 2003.

[9] M. J. Singer and A. I. Shainberg, "Mineral soil surface crusts and wind and water erosion," Earth Surface Processes and Landforms, vol. 29, no. 9, pp. 1065-1075, 2004.

[10] B. M. Ulén and T. Kalisky, "Water erosion and phosphorus problems in an agricultural catchment-need for natural research for implementation of the EU Water Framework Directive," Environmental Science and Policy, vol. 8, no. 5, pp. 477-484, 2005.

[11] J. M. García-Ruiz, "The effects of land uses on soil erosion in Spain: a review," Catena, vol. 81, no. 1, pp. 1-11, 2010.

[12] J. A. Nittrouer, J. Shaw, M. P. Lamb, and D. Mohrig, "Spatial and temporal trends for water-flow velocity and bed-material sediment transport in the lower Mississippi River," Bulletin of the Geological Society of America, vol. 124, no. 3-4, pp. 400-414, 2012.

[13] J.-P. Bravard, M. Goichot, and H. Tronchère, "An assessment of sediment-transport processes in the Lower Mekong River based on deposit grain sizes, the CM technique and flow-energy data," Geomorphology, vol. 207, pp. 174-189, 2014.

[14] C. L. Blanchet, R. Tjallingii, M. Frank et al., "High- and lowlatitude forcing of the Nile River regime during the Holocene inferred from laminated sediments of the Nile deep-sea fan," Earth and Planetary Science Letters, vol. 364, pp. 98-110, 2013.

[15] J.-J. Wang, X. X. Lu, and M. Kummu, "Sediment load estimates and variations in the Lower Mekong River," River Research and Applications, vol. 27, no. 1, pp. 33-46, 2011.

[16] Y. S. A. Ali, A. Crosato, Y. A. Mohamed, S. H. Abdalla, and N. G. Wright, "Sediment balances in the Blue Nile River Basin," International Journal of Sediment Research, vol. 29, no. 3, pp. 316-328, 2014.

[17] X. X. Lu and R. Y. Siew, "Water discharge and sediment flux changes over the past decades in the Lower Mekong River: possible impacts of the Chinese dams," Hydrology and Earth System Sciences, vol. 10, no. 2, pp. 181-195, 2006. 
[18] D. Conway, "The climate and hydrology of the Upper Blue Nile river," The Geographical Journal, vol. 166, no. 1, pp. 49-62, 2000.

[19] Y.-K. Zhang and K. E. Schilling, "Increasing streamflow and baseflow in Mississippi River since the 1940s: effect of land use change," Journal of Hydrology, vol. 324, no. 1-4, pp. 412-422, 2006.

[20] H. Y. Zhang, Z. H. Shi, N. F. Fang, and M. H. Guo, "Linking watershed geomorphic characteristics to sediment yield: evidence from the Loess Plateau of China," Geomorphology, vol. 234, pp. 19-27, 2015.

[21] C. S. Renschler and J. Harbor, "Soil erosion assessment tools from point to regional scales-the role of geomorphologists in land management research and implementation," Geomorphology, vol. 47, no. 2-4, pp. 189-209, 2002.

[22] A. Gobin, G. Govers, R. Jones et al., "Assessment and reporting on soil erosion," Tech. Rep., European Environment Agency, Copenhagen, Denmark, 2003.

[23] Z.-B. Xin, J.-X. Xu, and X.-X. Yu, “Temporal and spatial variability of sediment yield on the Loess Plateau in the past 50 years," Acta Ecologica Sinica, vol. 29, no. 3, pp. 1129-1139, 2009.

[24] R. Mukundan, S. M. Pradhanang, E. M. Schneiderman et al., "Suspended sediment source areas and future climate impact on soil erosion and sediment yield in a New York City water supply watershed, USA," Geomorphology, vol. 183, pp. 110-119, 2013.

[25] B. Pradhan, A. Chaudhari, J. Adinarayana, and M. F. Buchroithner, "Soil erosion assessment and its correlation with landslide events using remote sensing data and GIS: a case study at Penang Island, Malaysia," Environmental Monitoring and Assessment, vol. 184, no. 2, pp. 715-727, 2012.

[26] H. B. Mann, "Nonparametric tests against trend," Econometrica, vol. 13, pp. 245-259, 1945.

[27] M. G. Kendall, Rank Correlation Methods, Griffin, London, UK, 4th edition, 1948.

[28] G. Bing, Land-atmosphere coupling simulation and analysis of streamflow changes in the Yangtze River Basin [Ph.D. thesis], Tsinghua University, Beijing, China, 2012.

[29] F. Fathian, Z. Dehghan, M. H. Bazrkar, and S. Eslamian, “Trends in hydrologic and climatic variables affected by four variations of Mann-Kendall approach in Urmia Lake basin, Iran," Hydrological Sciences Journal, 2014.

[30] I. Ahmad, D. Tang, T. Wang, M. Wang, and B. Wagan, "Precipitation trends over time using Mann-Kendall and spearman's rho tests in swat river basin, Pakistan," Advances in Meteorology, vol. 2015, Article ID 431860, 15 pages, 2015.

[31] H. Hu, G. Wang, Z. Li et al., "Study on response of runoff of Weihe river to LUCC and climate changes," Yellow River, vol. 30, no. 7, pp. 25-26, 2008.

[32] W. H. Wischmeier and D. D. Smith, Predicting Rainfall Erosion Losses-A Guide to Conservation Planning, Science and Education Administration, 1978.

[33] E. Tunc, T. Iserloh, and Ş. Gülmezyüz, "Soil erosion mapping by application of RUSLE and GIS-technology in the Turkish province Gaziantep/Southeastern Anatolia," Journal of GIS Trends, vol. 4, no. 1, pp. 1-10, 2014.

[34] B. Jiang, GIS-Based Time Series Study of Soil Erosion Risk Using the Revised Universal Soil Loss Equation (Rusle) Model in a Micro-Catchment on Mount Elgon, Uganda, Student Thesis Series INES, 2013.

[35] T. Chen, R.-Q. Niu, P.-X. Li, L.-P. Zhang, and B. Du, "Regional soil erosion risk mapping using RUSLE, GIS, and remote sensing: a case study in Miyun Watershed, North China," Environmental Earth Sciences, vol. 63, no. 3, pp. 533-541, 2011.
[36] B. J. Fu, W. W. Zhao, L. D. Chen et al., "Assessment of soil erosion at large watershed scale using RUSLE and GIS: a case study in the Loess Plateau of China," Land Degradation \& Development, vol. 16, no. 1, pp. 73-85, 2005.

[37] G. Zhao, X. Mu, Z. Wen, F. Wang, and P. Gao, "Soil erosion, conservation, and eco-environment changes in the loess plateau of China," Land Degradation \& Development, vol. 24, no. 5, pp. 499-510, 2013.

[38] Y. Liu, B. Fu, Y. Lü, Z. Wang, and G. Gao, "Hydrological responses and soil erosion potential of abandoned cropland in the Loess Plateau, China," Geomorphology, vol. 138, no. 1, pp. 404-414, 2012.

[39] L. Wang, Z. H. Shi, J. Wang, N. F. Fang, G. L. Wu, and H. Y. Zhang, "Rainfall kinetic energy controlling erosion processes and sediment sorting on steep hillslopes: a case study of clay loam soil from the Loess Plateau, China," Journal of Hydrology, vol. 512, pp. 168-176, 2014.

[40] W. Sun, Q. Shao, and J. Liu, "Soil erosion and its response to the changes of precipitation and vegetation cover on the Loess Plateau," Journal of Geographical Sciences, vol. 23, no. 6, pp. 10911106, 2013.

[41] I. D. Moore and J. P. Wilson, "Length-slope factors for the revised universal soil loss equation: simplified method of estimation," Journal of Soil \& Water Conservation, vol. 47, no. 5, pp. 423-428, 1992.

[42] K. Van Oost, W. Van Muysen, G. Govers, J. Deckers, and T. A. Quine, "From water to tillage erosion dominated landform evolution," Geomorphology, vol. 72, no. 1-4, pp. 193-203, 2005.

[43] Z. Zhou and Z. Ren, "Correlation between land use and soil erosion intensities based on GIS: taking Loess Plateau in North Shaanxi Province as an example," Chinese Journal of Ecology, vol. 25, no. 6, pp. 629-634, 2006.

[44] S. Wang, G. Wang, and Z. Chen, "Relationship between land use and soil erosion in Yellow River Basin," Journal of Natural Disasters, vol. 1, article 004, 2005.

[45] A. H. Abu Salim, "Geomorphological analysis of the morphometric characteristics that determine the volume of sediment yield of Wadi Al-Arja, South Jordan," Journal of Geographical Sciences, vol. 24, no. 3, pp. 457-474, 2014.

[46] J. B. Zhao, J. Du, and C. C. Huang, "Study on erosion periods in Loess Plateau," Journal of Desert Research, vol. 22, no. 3, pp. 257-261, 2002.

[47] P. Gao, X. Zhang, X. Mu, F. Wang, R. Li, and X. Zhang, "Trend and change-point analyses of streamflow and sediment discharge in the Yellow River during 1950-2005," Hydrological Sciences Journal, vol. 55, no. 2, pp. 275-285, 2010.

[48] H. He, J. Zhou, M. R. Peart, J. Chen, and Q. Zhang, "Sensitivity of hydrogeomorphological hazards in the Qinling Mountains, China," Quaternary International, vol. 282, no. 1, pp. 37-47, 2012.

[49] H. He, J. Zhou, Q. Yu, Y. Q. Tian, and R. F. Chen, "Flood frequency and routing processes at a confluence of the middle Yellow River in China," River Research \& Applications, vol. 23, no. 4, pp. 407-427, 2007.

[50] H. He, Q. Yu, J. Zhou, Y. Q. Tian, and R. F. Chen, "Modelling complex flood flow evolution in the middle Yellow River basin, China," Journal of Hydrology, vol. 353, no. 1, pp. 76-92, 2008.

[51] J. X. Liu, Z. G. Li, X. P. Zhang, R. Li, X. Liu, and H. Zhang, "Responses of vegetation cover to the Grain for Green Program and their driving forces in the He-Long region of the middle reaches of the Yellow River," Journal of Arid Land, vol. 5, no. 4, pp. 511-520, 2013. 
[52] Y. Xie, B.-Y. Liu, and W.-B. Zhang, "Study on standard of erosive rainfall," Journal of Soil and Water Conservation, vol. 14, no. 4, pp. 6-11, 2000.

[53] K. Chang, Introduction to Geographic Information Systems, McGraw-Hill Higher Education, Boston, Mass, USA, 2006. 

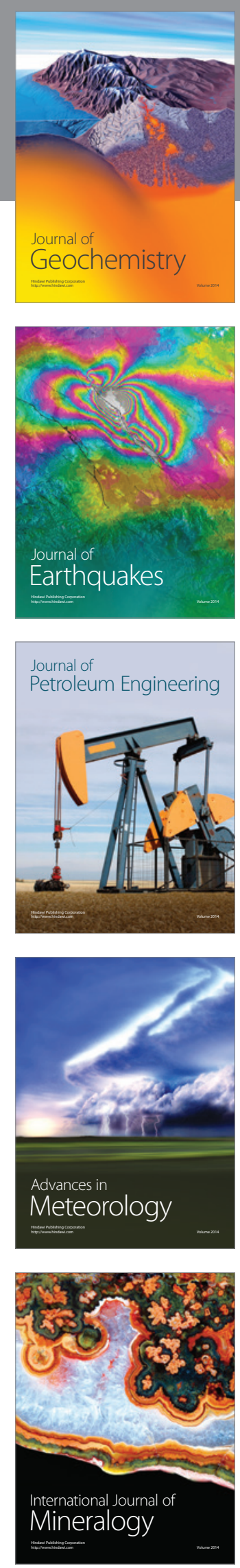
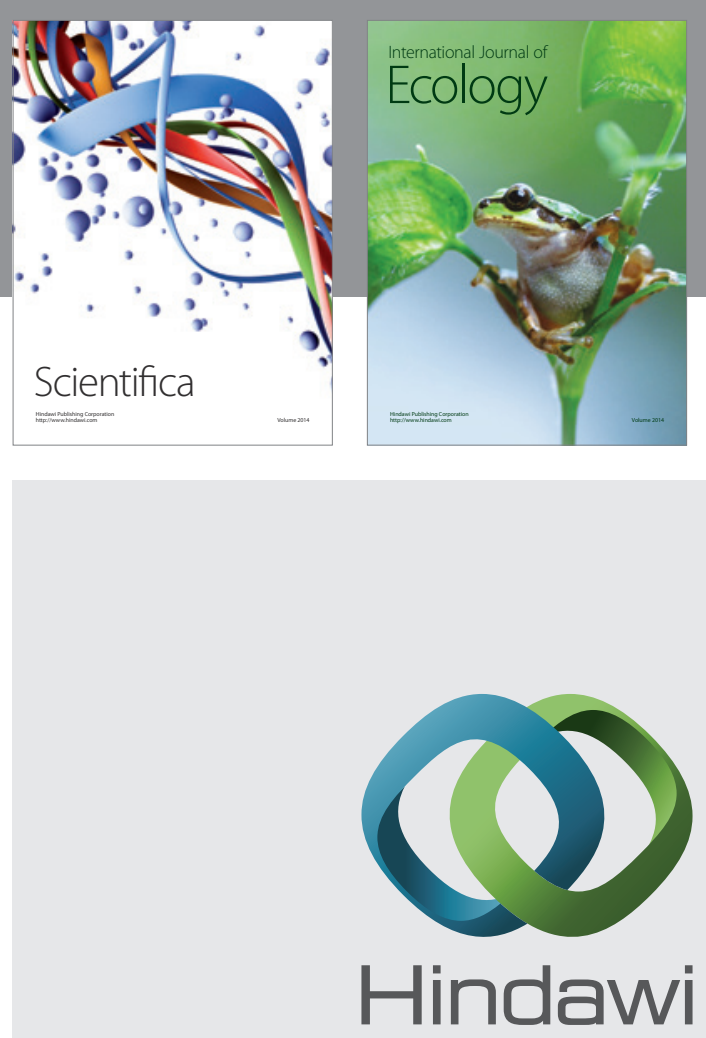

Submit your manuscripts at

http://www.hindawi.com
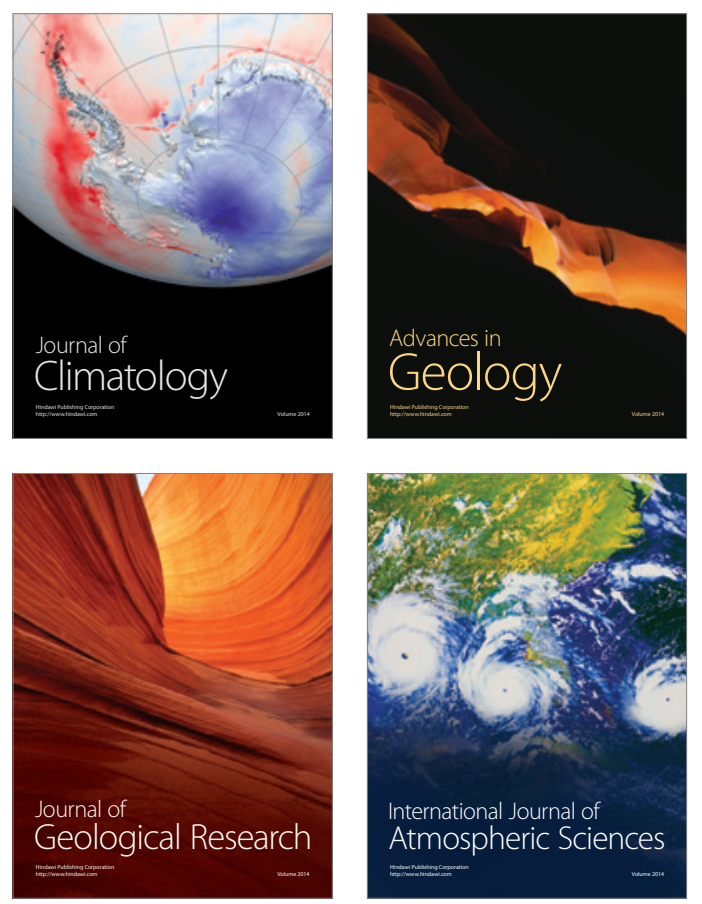

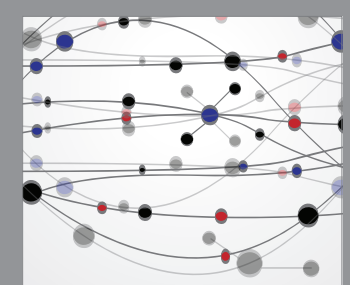

The Scientific

\section{World Journal}
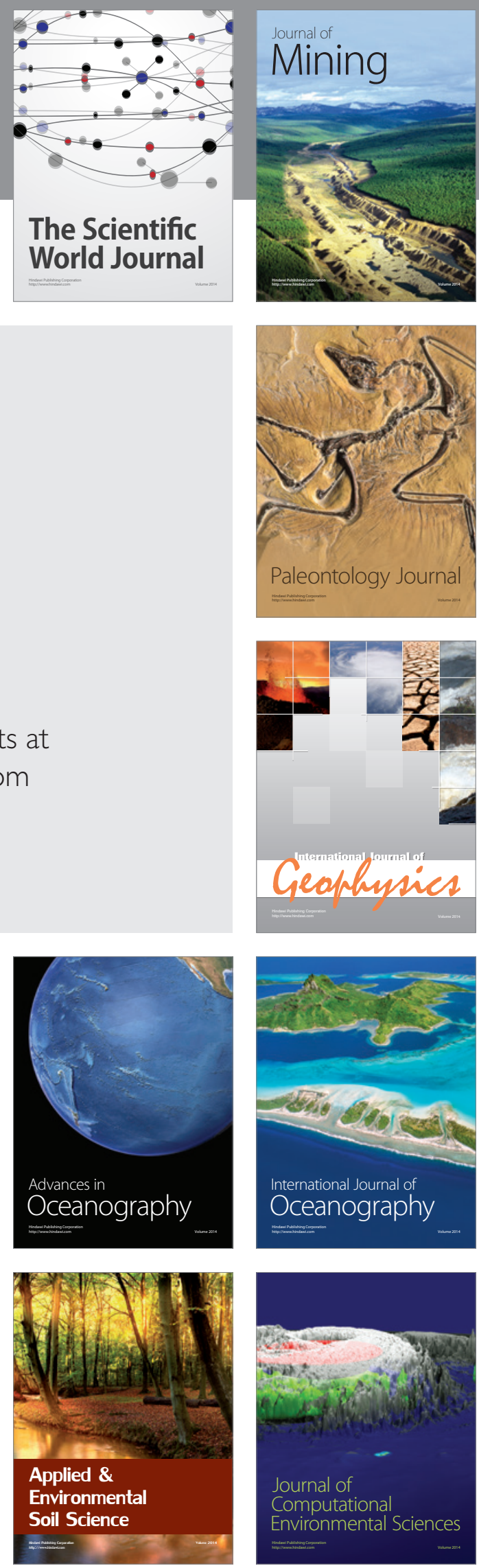